University of Windsor

Scholarship at UWindsor

2004

\title{
Mono- and disubstitutions of (hepta-2,5-diyne-1,7-diol) bis(dicobalt) derivatives - Selectivity in Nicholas reactions
}

Richard Guo

Romelo Gibe

James R. Green

University of Windsor

Follow this and additional works at: https://scholar.uwindsor.ca/chemistrybiochemistrypub

Part of the Chemistry Commons

\section{Recommended Citation}

Guo, Richard; Gibe, Romelo; and Green, James R.. (2004). Mono- and disubstitutions of (hepta-2,5-diyne-1,7-diol) bis(dicobalt) derivatives - Selectivity in Nicholas reactions. Canadian Journal of Chemistry-Revue Canadienne De Chimie, 82 (2), 366-374.

https://scholar.uwindsor.ca/chemistrybiochemistrypub/14

This Article is brought to you for free and open access by the Department of Chemistry and Biochemistry at Scholarship at UWindsor. It has been accepted for inclusion in Chemistry and Biochemistry Publications by an authorized administrator of Scholarship at UWindsor. For more information, please contact scholarship@uwindsor.ca. 
Mono- and Disubstitutions of (Hepta-2,5-diyne-1,7-diol) Bis(dicobalt) Derivatives: Selectivity in Nicholas Reactions ${ }^{1}$

Richard Guo, Romelo Gibe, and James R. Green ${ }^{*}$

*Department of Chemistry and Biochemistry, University of Windsor, Windsor, ON, N9B 3P4, Canada

Telephone: (519)-253-3000, ext. 3545; Fax: (519)-973-7098; e-mail: jgreen@uwindsor.ca

\footnotetext{
${ }^{1}$ Dedicated to Professor Ed Piers for his many contributions to terpene chemistry and the application of organometallic chemistry to organic synthesis.
} 


\begin{abstract}
:
Bis(hexacarbonyldicobalt) complexes of benzyl ether/methyl ether or benzyl ether/acetate derivatives of hepta-2,5-diyne-1,7-diols undergo selective Lewis acid mediated Nicholas reactions with enol silanes, silyl ketene acetals, and allylstannanes, preferentially replacing the methyl ether or acetate function. Hydride nucleophiles are similarly incorporated selectively using a benzyl ether/alcohol derivative. Subsequent Nicholas reaction at the benzyloxy- bearing site may be accomplished with an identical or a different nucleophile, affording skipped 1,4diyne- $\mathrm{Co}_{4}(\mathrm{CO})_{12}$ complexes. In instances of lower selectivity for monosubstitution reactions with benzyl ethers, reverting to the use of a menthyl ether/methyl ether complex gives much improved selectivity for methyl ether substitution.
\end{abstract}

\title{
Key words:
}

Cobalt alkyne complexes, Nicholas reaction, Lewis acids, 1,4-diynes 
The chemistry of propargylhexacarbonyldicobalt cations, or the Nicholas reaction, has seen extensive use in organic synthesis. ${ }^{1}$ This interest stems from the predictable regiochemical and stereochemical aspects of the Nicholas reaction, and from the ability of cobalt alkyne complexes to protect the alkyne unit, ${ }^{2}$ to allow non-conventional alkyne geometries, to participate in synthetically useful cycloaddition reactions, ${ }^{3,4,5}$ and to alter the steric size of the formal alkyne function. ${ }^{6}$

We have been interested in the use of tandem Nicholas reactions, both of derivatives of butyne-1,4-diol cobalt complexes, and of derivatives of bis(propargyl alcohol) complexes, for a number of synthetic purposes. ${ }^{7}$ The matter of selectivity where two sites for Nicholas reaction chemistry exist is an important issue, but this has been addressed only on rare occasion in butyne-1,4-diol- $\mathrm{Co}_{2}(\mathrm{CO})_{6}$ derivatives, ${ }^{7 \mathrm{~b}, 8}$ and not at all in the case of bis(propargyl alcohol)$\mathrm{Co}_{4}(\mathrm{CO})_{12}$ derivatives. ${ }^{9}$ Furthermore, substrates that would serve as synthons for skipped bis(propargyl) cations 1 selectively would give rise to 1,4-diyne complexes $\mathbf{2}$, which are promising intermediates in the synthesis of compounds with skipped diene, diyne, or enyne functions, such as petrocortynes/petroformynes/ petrosiacetylenes, ${ }^{10}$ eicosanoids and oxoeicosanoids, ${ }^{11}$ including several of the leukotrienes. ${ }^{12}$ Consequently, we deemed the study of the selectivity in Nicholas reactions of $\mathbf{3}$ to be of importance; we have reported in preliminary form the substitution reactions of $\mathbf{3}$ and wish to more fully describe our efforts in this area. ${ }^{13}$

\section{Suggested location for structures 1-3}

The requisite heptyne-1,7-diol derivatives were prepared from benzyl propargyl ether (Scheme 1). Copper (I) catalyzed coupling of the corresponding bromomagnesium acetylide with propargyl bromide afforded diyne 4 (78\% yield), which was functionalized in two ways. Deprotonation of $\mathbf{4}$ with MeLi and exposure of the resultant acetylide to chloromethyl methyl 
ether gave benzyl methyl diether 5a (59\% yield). Alternatively, treatment of the same lithium acetylide with paraformaldehyde gave ether alcohol 6 (55\% yield), and subsequent acetylation with acetic anhydride/ $\mathrm{BF}_{3}-\mathrm{OEt}_{2}$ afforded the benzyl ether acetate $\mathbf{5 b}$ ( $69 \%$ yield). The bis(hexacarbonyldicobalt) complexes of the diynediol derivatives were then prepared in a straightforward manner by subjecting $\mathbf{5 a}$ and $\mathbf{5 b}$ to excess $\mathrm{Co}_{2}(\mathrm{CO})_{8}$, to give $\mathbf{3 a}$ (77\% yield) and 3b (78\% yield), respectively.

\section{Suggested location for Scheme 1}

With two related substrates in hand, we investigated reactions of $\mathbf{3 a}$ and $\mathbf{3 b}$ with a series of representative nucleophiles, including the allylmetals allyltributylstannane (7a) and allyltrimethylsilane (7b), propiophenone trimethylsilyl enol ether (7c), ethyl cyclohexanecarboxylate trimethylsilyl ketene acetal (7d), and cyclohexanone trimethylsilyl enol ether (7e), all mediated by $\mathrm{BF}_{3}-\mathrm{OEt}_{2}$ (Scheme 2).

\section{Suggested location for structures $7 a-7 f$}

\section{Suggested location for Scheme 2}

Allylation of $\mathbf{3 a}$ or $\mathbf{3 b}$ could be accomplished by either allyltributylstannane or allyltrimethylsilane; allyltributyltin, however, proved to be the significantly superior nucleophile for monosubstitution reactions. In the case of methyl ether $\mathbf{3 a}$, for example, reaction of 1.0 equiv of $\mathrm{BF}_{3}-\mathrm{OEt}_{2}$ at $0{ }^{\circ} \mathrm{C}$ with 2.0 equiv allyltrimethylsilane gave $8 \mathbf{a}$ in a $39 \%$ yield $(80 \%$ yield based on recovered starting material), and considerable recovered 3a. Additional amounts of $\mathrm{BF}_{3}-\mathrm{OEt}_{2}$ caused greater conversion, but afforded significant amounts of diallylated 9a. Conversely, allyltributyltin afforded a $63 \%$ yield of $\mathbf{8 a}(82 \%$ based on recovered starting material [brsm] 3a) in the presence of 2.0 equiv of $\mathrm{BF}_{3}-\mathrm{OEt}_{2}\left(0{ }^{\circ} \mathrm{C}, 2\right.$ equiv allyltributyltin) with more manageable amounts of unreacted $\mathbf{3 a}(24 \%)$ and $\mathbf{9 a}$ ( $7.5 \%$ yield). With acetate $\mathbf{3 b}$, reasonable results could 
be obtained with 1.5 equiv $\mathrm{BF}_{3}-\mathrm{OEt}_{2}\left(0{ }^{\circ} \mathrm{C}, 1.5\right.$ equiv allyltributyltin), giving $\mathbf{8 a}$ (62\% yield, $75 \%$ yield based on recovered starting $\mathbf{3 b}$ ), with $17 \%$ recovered $\mathbf{3 b}$ (Table 1).

This necessity to optimize nucleophile/electrophile/Lewis acid stoichiometries in each case proved to be a general requirement with $\mathbf{3 a}$ and $\mathbf{3 b}$ and all nucleophiles, but allowed for satisfactory amounts of monosubstitution products in most cases, normally by stopping at the $80 \%-90 \%$ conversion range. The substitution of silyl enol ether $\mathbf{7 c}$ with $\mathbf{3 b}$ was found to be able to give $\mathbf{8 b}$ in a $64 \%$ yield (70\% brsm), while silyl ketene acetal $\mathbf{7 d}$ with $\mathbf{3 b}$ gave a $63 \%$ yield (70\% brsm) of $\mathbf{8 c}$. Silyl enol ether $\mathbf{7 e}$ proved somewhat less selective, and reactions were terminated at lower conversion levels (60-70\%) in order to minimize disubstitution. Under these circumstances, acetate $\mathbf{3 b}$ afforded $\mathbf{8 d}$ in $41 \%$ (70\% brsm), while with methyl ether $\mathbf{3 a}, \mathbf{8 d}$ could be obtained in $43 \%$ yield ( $76 \%$ brsm).

Intentional disubstitution reactions were attempted in two cases, using excess $\mathrm{BF}_{3}-$ $\mathrm{OEt}_{2} /$ nucleophile combinations (4 equiv each). In the case of diallylation of $\mathbf{3 a}$, allyltributylstannane proved satisfactory, giving $\mathbf{9 a}$ (73\% yield) along with $12 \%$ of $\mathbf{8 a}$. Nevertheless, allyltrimethylsilane was superior in this regard, as complete consumption of 3a occurred to give 9a in 90\% yield. Propiophenone trimethylsilyl enol ether $\mathbf{7 c}$ also was amenable to giving disubstitution, transforming $\mathbf{3 b}$ to $\mathbf{9 b}$ as a 1:1 diastereomeric mixture (70\% yield).

\section{Suggested location for Table 1}

In addition to the persubstitution reactions described above, we wished to determine whether this framework possessed the ability to incorporate two different nucleophiles in disubstitution reactions. For this purpose, we chose allylation product $\mathbf{8 a}$, by virtue of the low reactivity of the isolated alkene function to many Lewis acid/nucleophile combinations. In the event, 8a was subjected to reaction with $\mathrm{BF}_{3}-\mathrm{OEt}_{2}$ and 1,3,5-trimethoxybenzene (7f) (2 equiv 
each, $0{ }^{\circ} \mathrm{C}$ ). The benzyloxy function was replaced cleanly, and 10 a could be isolated in $95 \%$ yield. Ester substituted $\mathbf{8 c}$ also was successful in substitution by a second nucleophile, as allyltrimethylsilane and $\mathrm{BF}_{3}-\mathrm{OEt}_{2}\left(2.0\right.$ equiv each, $\left.0^{\circ} \mathrm{C}\right)$ gave $10 \mathrm{~b}$ in $76 \%$ yield.

\section{Suggested location for Scheme 3}

As a final choice of nucleophile for Nicholas substitution reactions, we also chose to look at a stannane to induce an overall reduction. In this case, we selected substrate 11, due to the $n$ pentyl group often bring present as a (Z)-alkene substituent in leukotriene systems, and due to the fact that an alcohol function should be ionizable without destruction of the stannane nucleophile. This compound was prepared from $\mathbf{4}$, by trapping of the lithium acetylide with pentanal, and reaction of unpurified alcohol 12 with $\mathrm{Co}_{2}(\mathrm{CO})_{8}$ to form 11 (44\% yield from 4) (Scheme 4).

Reduction of 11 with $\mathrm{BF}_{3}-\mathrm{OEt}_{2}$ and a reactive stannane such as $\mathrm{Bu}_{3} \mathrm{SnH}$ and $\mathrm{Me}_{3} \mathrm{SnH}$ tended to be unselective, tending to give complete reduction of the alcohol and ether functions. Using the less reactive $\mathrm{Ph}_{3} \mathrm{SnH}$ and $\mathrm{BF}_{3}-\mathrm{OEt}_{2}$ under carefully controlled conditions gave greater selectivity, however. At $5{ }^{\circ} \mathrm{C}$, with 1.5 equiv $\mathrm{Ph}_{3} \mathrm{SnH}$ with 1.0 equiv $\mathrm{BF}_{3}-\mathrm{OEt}_{2}$, total selectivity for reduction of the alcohol could be realized, and $\mathbf{1 3}$ (84\% yield) was isolated as the sole product.

\section{Suggested location for Scheme 4}

The results in Table 1 demonstrate that, in most cases, the benzyloxy function served as an acceptable potential leaving group which would be retained in monosubstitution reactions in deference to alcohol, methyl ether, or acetate functions. In the cases of allyltrimethylsilane (7a) and cyclohexanone silyl enol ether (7e) as the nucleophile, the reactions had to be terminated at relatively low levels of conversion and as a result the isolated yields of monosubstitution products $8 \mathbf{a}$ and $8 \mathbf{d}$ were limited. We deemed the selectivity in these cases insufficient, and 
chose to investigate alternatives which would give greater discrimination between oxygen functions, and hence greater monosubstitution selectivity. We have observed selectivity in Nicholas reaction-based $4+3$ cycloaddition chemistry by employing an isopropyl ether as the more slowly ionizing oxygen function. ${ }^{7 b}$ Due to its straightforward preparation relative to isopropyl propargyl ether, ${ }^{14}$ we chose instead menthyloxy containing $14^{15}$ as a starting point. The bromomagnesium acetylide of this propargylic ether was coupled with propargyl bromide to afford diyne 15 (75\% yield), which in turn was converted to the menthyl methyl diynyl diether bis(dicobalt) complex 16 by deprotonation and subsequent trapping with chloromethyl methyl ether, and exposure of unpurified intermediate $\mathbf{1 7}$ to $\mathrm{Co}_{2}(\mathrm{CO})_{8}(72 \%$ yield overall from 15) (Scheme 1).

With complex 16 in hand, we investigated its reactivity towards allyltrimethylsilane (7a) and cyclohexanone trimethylsilyl enol ether (7e). With allyltrimethylsilane, the use of near stoichiometric amounts of Lewis acid $\mathrm{BF}_{3}-\mathrm{OEt}_{2}$ resulted in the recovery of substantial amounts of starting 16. For example, with even two equivalents of $\mathrm{BF}_{3}-\mathrm{OEt}_{2}$, allyltrimethylsilane (1.5 equiv, $\left.12 \mathrm{~h},-10{ }^{\circ} \mathrm{C}\right), 31 \%$ recovery of $\mathbf{1 6}$ was found in addition to $\mathbf{1 8 a}(31 \%, 54 \%$ based on recovered 16). The amount of conversion increased with further excess amounts of $\mathrm{BF}_{3}-\mathrm{OEt}_{2}$, and at 4 equiv, $\mathbf{1 6}$ was consumed completely and a 71\% yield of 18a was obtained (Scheme 5). Further increased amounts of Lewis acid gave a gradual degradation of product yield.

In the case of cyclohexanone trimethylsilyl enol ether (7e), an analogous trend was found with increasing amounts of $\mathrm{BF}_{3}-\mathrm{OEt}_{2}$, but modest amounts of starting material remained even at 4 equiv ( $6 \% \mathbf{1 6}$ recovery, $52 \%$ yield of $\mathbf{1 8 b}, 60 \%$ yield brsm). In this case, switching the Lewis acid to $\mathrm{Bu}_{2} \mathrm{BOTf}$ (1.2 equiv), in addition to an excess ( 3 equiv) of nucleophile gave an improved yield $(71 \%)$ of $\mathbf{1 8 b}$, while greater excesses of this Lewis acid gave near-complete destruction of 
the product. In the case of $\mathbf{1 8 b}$, a new chiral centre was generated. An apparent doubling of the several of signals was apparent in both the ${ }^{1} \mathrm{H}$ and ${ }^{13} \mathrm{C}$ NMR spectra of $\mathbf{1 8 b}$, and integration of the signals showed that $\mathbf{1 8 b}$ existed as a 1:1 diastereomeric mixture. This was most clearly apparent for ${ }^{1} \mathrm{H}$ NMR resonances for the diastereotopic propargyl methylene group $\alpha$ - to the ether oxygen, which resonated at 4.851 and $4.847 \mathrm{ppm}$, and 4.53 and $4.52 \mathrm{ppm}$ for the two diastereomers. Due to the distance between the reacting centre and the nearest centre of chirality, this lack of asymmetric induction was not surprising.

\section{Suggested location for Scheme 5}

We chose 18a for study in order to determine whether the removal of the menthyloxy group was facile. Again, the substrate proved to be relatively sluggish in terms of reaction, but in the presence of 3 equiv each of $\mathrm{BF}_{3}-\mathrm{OEt}_{2}$ and $\mathrm{MeOH}\left(0{ }^{\circ} \mathrm{C}, \mathrm{CH}_{2} \mathrm{Cl}_{2}\right)$, methoxy substitution product 19 could be obtained in $65 \%$ yield ( $75 \%$ based on recovered starting material).

A combination of these results with those of reference $7 b^{7 b}$ suggests the following approximate order in the kinetic ionization of oxygen based functions in Nicholas reactions: $\mathrm{OH}$ $>\mathrm{OMe}, \mathrm{OAc}>\mathrm{OBn}>\mathrm{OPr}^{\mathrm{i}}$, O-menthyl, OTBDMS. The dominant factor in this ordering is most likely steric accessibility to the oxygen atom, although it is likely that inductive effects in the benzyl ether plays some role in reducing its basicity. A lower basicity of the acetate function is also known, ${ }^{16,17}$ but is offset by its innately better leaving group ability.

With respect to the nucleophiles concerned, no clear pattern of nucleophile reactivity versus selectivity has emerged. For example, in the case of allylation, the more reactive allylstannane gives greater selectivity for monosubstitution; by contrast, a less reactive tin hydride $\left(\mathrm{Ph}_{3} \mathrm{SnH} \text { versus } \mathrm{Bu}_{3} \mathrm{SnH} \text { or } \mathrm{Me}_{3} \mathrm{SnH}\right)^{18}$ is more productive in reductions. Nevertheless, by careful choice of conditions and nucleophile, synthetically useful amounts of selective 
monosubstitution products can be obtained in most cases using the benzyl substrates $\mathbf{3 a}$ and $\mathbf{3 b}$. Disubstitution reactions of with either two identical or two different nucleophiles can also be accomplished in good to excellent yields. With the poorer cases for $\mathbf{3 a}$ or $\mathbf{3 b}$, the menthyl ether complex 16 gives very good selectivity for monosubstitution; in fact, the menthoxy group is removed at all only sluggishly.

\section{Experimental Section}

\section{General methods}

All solvents were used after distillation from the appropriate drying agent. Diethyl ether and THF were distilled from benzophenone ketyl immediately prior to use. Dichloromethane was distilled from $\mathrm{CaH}_{2}$ immediately prior to use. Commercial $\mathrm{BF}_{3}-\mathrm{OEt}_{2}$ was distilled and stored under nitrogen. All reactions were performed under nitrogen unless otherwise noted. Flash chromatography was performed as described by Still ${ }^{19}$ using (230 - 240 mesh) silica gel 60.

NMR spectra were run at $500 \mathrm{MHz}$ or $300 \mathrm{MHz}$ for ${ }^{1} \mathrm{H}$, and $125 \mathrm{MHz}$ or $75 \mathrm{MHz}$ for ${ }^{13} \mathrm{C}$ in $\mathrm{CDCl}_{3}$; chemical shifts are given in ppm and coupling constants $(J)$ are given in $\mathrm{Hz}$. Mass spectra were run at the Chemistry and Biochemistry Mass Spectrometry Facility, University of Windsor, and the Mass Spectrometry Facility, Wayne State University.

6-Benzyloxy-1,4-hexadiyne (4). To the freshly prepared EtMgBr (25 mmol) in dry THF (20 mL) was added 3-benzyloxy-1-propyne (3.000 g, $20.00 \mathrm{mmol})$ over $10 \mathrm{~min}$. After several minutes, the THF began to reflux. When the exothermic reaction had subsided, the flask was warmed for 30 min at $55^{\circ} \mathrm{C}$. The solution was then cooled to $30^{\circ} \mathrm{C}$ and powdered $\mathrm{CuCl}(60 \mathrm{mg})$ was added. After 15 min, propargyl bromide $(2.2 \mathrm{~mL}, 20 \mathrm{mmol})$ was added over $30 \mathrm{~min}$. The mixture was warmed for $1 \mathrm{~h}$ to $60{ }^{\circ} \mathrm{C}$. After cooling to room temperature, the reaction mixture was poured into a solution of $\mathrm{NH}_{4} \mathrm{Cl}(3.0 \mathrm{~g})$ and $\mathrm{KCN}(100 \mathrm{mg})$ in water $(10 \mathrm{~mL})$. After 
vigorous shaking, the reaction was subjected to a conventional workup. Flash chromatography (petroleum ether:diethyl ether, 10:1) followed by distillation afforded 4 $\left(1.160\right.$ g, $78 \%$ ): b.p. $116-120^{\circ} \mathrm{C} / 0.5$ torr; IR (neat, $\left.\mathrm{NaCl}\right) v_{\max } 3292,3030,2856,1496 \mathrm{~cm}^{-1}$; ${ }^{1} \mathrm{H}$ NMR $\delta 7.35(\mathrm{~m}, 5 \mathrm{H}), 4.62(\mathrm{~s}, 2 \mathrm{H}), 4.20(\mathrm{t}, \mathrm{J}=3.4,2 \mathrm{H}), 3.26(\mathrm{~m}, 2 \mathrm{H}), 2.13(\mathrm{t}, \mathrm{J}=4.5,1$ $\mathrm{H}) ;{ }^{13} \mathrm{C}$ NMR $\delta 137.9,128.8,128.5,128.3,80.4,78.2,77.9,72.0,69.5,57.9,10.1 ; \mathrm{MS} \mathrm{m} / \mathrm{e}$ $184\left(\mathrm{M}^{+}\right)$; HRMS m/e for $\mathrm{C}_{13} \mathrm{H}_{12} \mathrm{O}$ calcd $\left(\mathrm{M}^{+}\right)$184.0888, found 184.0886.

7-Benzyloxy-2,5-heptadiyn-1-ol (6). To $4(1.000 \mathrm{~g}, 5.4 \mathrm{mmol})$ in dry $\mathrm{Et}_{2} \mathrm{O}(10 \mathrm{~mL})$ was added $\mathrm{MeLi}\left(1.5 \mathrm{M}\right.$ in $\left.\mathrm{Et}_{2} \mathrm{O}, 3.6 \mathrm{~mL}, 5.4 \mathrm{mmol}\right)$ at $-78^{\circ} \mathrm{C}$ over $20 \mathrm{~min}$. Thereafter, the solution was warmed to $-30{ }^{\circ} \mathrm{C}$ and paraformaldehyde $(300 \mathrm{mg}$ ) was added. After $45 \mathrm{~min}$, the mixture was heated under reflux for $3 \mathrm{~h}$. After cooling to room temperature, the mixture was poured into ice water $(10 \mathrm{~mL})$, and a conventional workup performed. Flash chromatography (petroleum ether-diethyl ether, 1:1) followed by distillation afforded 6 (640 mg, 55\%): b.p. $125-129{ }^{\circ} \mathrm{C} / 0.5$ torr; IR (neat, $\left.\mathrm{NaCl}\right) v_{\max } 3402,3030,2914,2282 \mathrm{~cm}^{-1} ;{ }^{1} \mathrm{H}$ NMR $\delta$ 7.27-7.35 (m, 5H), $4.60(\mathrm{~s}, 2 \mathrm{H}), 4.28(\mathrm{~s}, 2 \mathrm{H}), 4.18(\mathrm{t}, \mathrm{J}=2.1,2 \mathrm{H}), 3.29(\mathrm{~m}, 2 \mathrm{H}), 1.62(\mathrm{~s}, 1 \mathrm{H})$; ${ }^{13}$ C NMR 137.7, 128.8, 128.5, 128.3, 80.9, 79.8, 79.5, 77.1, 72.1, 57.9, 51.4, 10.4; MS m/e 214 $\left(\mathrm{M}^{+}\right)$; HRMS m/e for $\mathrm{C}_{14} \mathrm{H}_{14} \mathrm{O}_{2}$ calcd $\left(\mathrm{M}^{+}\right)$214.0994, found 214.0990.

1-Acetoxy-7-benzyloxy-2,5-heptadiyne (5b). To a mixture of compound 6 (1.200 g, 5.60 mmol $)$ and $\mathrm{Ac}_{2} \mathrm{O}(0.75 \mathrm{~mL}, 8.4 \mathrm{mmol})$ in $\mathrm{THF}(10 \mathrm{~mL})$ was added an excess of $\mathrm{BF}_{3}-\mathrm{Et}_{2} \mathrm{O}$ at -78 ${ }^{\circ} \mathrm{C}$ over a period of $20 \mathrm{~min}$. The reaction was warmed to $0{ }^{\circ} \mathrm{C}$, and monitored by TLC. After 1.5 $\mathrm{h}$, when the starting material had disappeared, the reaction mixture was poured into saturated $\mathrm{NaHCO}_{3}$ (aq). After a conventional workup, flash chromatography (petroleum ether:diethyl ether, 1:1) afforded product $\mathbf{5 b}(985 \mathrm{mg}, 69 \%)$ : bp 108-110 $\mathrm{C} / 0.5$ torr; IR (neat, $\mathrm{NaCl}) v_{\max } 3030,2929$, 2280, 1722, 1604, $1495 \mathrm{~cm}^{-1} ;{ }^{1} \mathrm{H}$ NMR $\delta$ 7.27-7.40 (m, 5H), $4.68(\mathrm{t}, \mathrm{J}=2.1,2 \mathrm{H}), 4.59$ (s, 2H), 
$4.17(\mathrm{t}, \mathrm{J}=2.1,2 \mathrm{H}), 3.29$ (pentet, $\mathrm{J}=2.1,2 \mathrm{H}), 2.09(\mathrm{~s}, 3 \mathrm{H}) ;{ }^{13} \mathrm{C}$ NMR 170.0, 137.3, 128.3, 128.0, 127.8, 80.6, 79.8, 76.8, 74.6, 71.6, 57.4, 52.3, 20.6, 9.9; MS: m/e $256\left(\mathrm{M}^{+}\right)$; HRMS: m/e for $\mathrm{C}_{16} \mathrm{H}_{16} \mathrm{O}_{3}$ calcd. $\left(\mathrm{M}^{+}\right)$256.1099, found 256.1100.

\section{Dodecacarbonyl $\left[\mu^{4}-(\eta, \eta, \eta, \eta)(1\right.$-acetoxy-7-benzyloxy-2,5-heptadiyne) $]$ tetracobalt (2 Co-Co)} $(\mathbf{3 b})$

General Procedure for Complexation. To a solution of $\mathbf{5 b}(1.000 \mathrm{~g}, 3.90 \mathrm{mmol})$ in anhydrous $\mathrm{Et}_{2} \mathrm{O}(20 \mathrm{~mL})$ at $0{ }^{\circ} \mathrm{C}$ was added an excess of dicobalt octacarbonyl. After $4 \mathrm{~h}$, the reaction mixture was allowed to warm to room temperature. The resulting mixture was filtered through Celite $^{\circledR}$ and the solvent was removed in vacuo. Flash chromatography (petroleum ether:diethyl ether, 15:1) afforded product $3 \mathbf{b}$ (2.580 g, 78\%): IR (neat, $\mathrm{NaCl}) v_{\max } 3031,2922,2860,2087$, 2034, 1742, $1626 \mathrm{~cm}^{-1} ;{ }^{1} \mathrm{H}$ NMR $\delta$ 7.27-7.39 (m, 5H), 5.30 (s, 2H), 4.69 (s 2H), 4.66 (s, 2H), 4.61 (s, 2H), 2.09 (s, 3H); ${ }^{13} \mathrm{C}$ NMR 199.4, 170.5, 137.7, 128.4, 127.7, 127.6, 92.8, 91.5, 91.1, 90.3, 73.1, 69.9, 64.3, 41.0, 20.3; MS (LSIMS) m/e $827(\mathrm{M}-1)^{+}, 744(\mathrm{M}-3 \mathrm{CO})^{+}, 688(\mathrm{M}-5 \mathrm{CO})^{+}$, 660 (M-6CO) ${ }^{+}$. Anal. Calcd. for $\mathrm{C}_{28} \mathrm{H}_{16} \mathrm{Co}_{4} \mathrm{O}_{15}: \mathrm{C}, 40.61 \% ; \mathrm{H}, 1.95 \%$. Found: C, 40.49\%; H, $1.88 \%$.

1-Benzyloxy-7-methoxy-2,5-heptadiyne (5a). To a solution of compound 4 (480 mg, 2.60 mmol) in dry $\mathrm{Et}_{2} \mathrm{O}(10 \mathrm{~mL})$ was added $\mathrm{MeLi}\left(1.48 \mathrm{M}\right.$ in $\left.\mathrm{Et}_{2} \mathrm{O}, 2.2 \mathrm{~mL}, 3.3 \mathrm{mmol}\right)$ at $-78{ }^{\circ} \mathrm{C}$ over $20 \mathrm{~min}$. The mixture was stirred for $30 \mathrm{~min}$ at $-78{ }^{\circ} \mathrm{C}$. Chloromethyl methyl ether $(0.20 \mathrm{~mL}, 2.60 \mathrm{mmol})$ was added dropwise over $20 \mathrm{~min}$, and the temperature was then allowed to rise to room temperature. The reaction was kept at room temperature for $2 \mathrm{~h}$. Thereafter, cold water was added and the mixture subjected to a conventional workup. Flash chromatography (petroleum ether:diethyl ether, 10:1) afforded product 5a (330 mg, 59\%): bp: $112-114{ }^{\circ} \mathrm{C} / 0.5$ torr; IR (neat, $\mathrm{NaCl}$ ) $v_{\max } 3031,2929,2280,1604,1495 \mathrm{~cm}^{-1} ;{ }^{1} \mathrm{H}$ 
NMR $\delta$ 7.27-7.37 (m, 5H), $4.60(\mathrm{~s} 2 \mathrm{H}), 4.18(\mathrm{t}, \mathrm{J}=2.0,2 \mathrm{H}), 4.10(\mathrm{t}, \mathrm{J}=2.0,2 \mathrm{H}), 3.38(\mathrm{~s}$, 3H), $3.30(\mathrm{t}, \mathrm{J}=2.0,2 \mathrm{H}) ;{ }^{13} \mathrm{C}$ NMR 137.2, 128.1, 127.7, 127.5, 80.1, 80.0, 76.4, 76.3, 71.2, 59.6, 57.2, 57.1, 9.6; MS m/e $228\left(\mathrm{M}^{+}\right)$; HRMS m/e for $\mathrm{C}_{15} \mathrm{H}_{16} \mathrm{O}$ calcd $\left(\mathrm{M}^{+}\right)$228.1150, found 228.1155 .

\section{Dodecacarbonyl $\left[\mu^{4}-(\eta, \eta, \eta, \eta)(1-b e n z y l o x y-7-m e t h o x y-2,5\right.$-heptadiyne $\left.)\right]$ tetracobalt $(2$}

Co-Co) (3a). Compound 5a (300 $\mathrm{mg}, 1.32 \mathrm{mmol})$ was subjected to reaction with $\mathrm{Co}_{2}(\mathrm{CO})_{8}$ via the general procedure. Flash chromatography (petroleum ether:diethyl ether, 20:1) afforded product 3a $(810 \mathrm{mg}, 77 \%)$ : IR (neat, $\mathrm{NaCl}) v_{\max } 3033,2926,2087,2049,2021 \mathrm{~cm}^{-}$ ${ }^{1} ;{ }^{1} \mathrm{H}$ NMR $\delta$ 7.27-7.39 (m, 5H), 4.73 (s, 2H), 4.69 (s, 2H), 4.65 (s, 2H), 4.57 (s, 2H), 3.44 (s, 3H); ${ }^{3} \mathrm{C}$ NMR 199.6, 137.9, 128.4, 127.7, 127.5, 93.1, 92.7, 91.5, 91.2, 73.1, 72.6, 69.8, 58.8, 41.1; MS (EI) m/e $744(\mathrm{M}-2 \mathrm{CO})^{+}, 716(\mathrm{M}-3 \mathrm{CO})^{+}$; (LSIMS) m/e $799(\mathrm{M}-1)^{+}, 716(\mathrm{M}-$ $3 \mathrm{CO})^{+}, 632(\mathrm{M}-6 \mathrm{CO})^{+}$.

Dodecacarbonyl $\left[\mu^{4}-(\eta, \eta, \eta, \eta)(1-b e n z y l o x y-9-e n e-2,5-d e c a d i y n e)\right]$ tetracobalt $(2$ Co-Co) (8a). General Procedure for Substitution Reactions. To a solution of compound $\mathbf{3 b}$ (300 $\mathrm{mg}, 0.36 \mathrm{mmol})$ and nucleophile $7 \mathbf{b}(179 \mathrm{mg}, 0.54 \mathrm{mmol})$ in $\mathrm{CH}_{2} \mathrm{Cl}_{2}(15 \mathrm{~mL})$ at $0{ }^{\circ} \mathrm{C}$ was added freshly distilled $\mathrm{BF}_{3}-\mathrm{Et}_{2} \mathrm{O}(77 \mathrm{mg}, 0.54 \mathrm{mmol})$ dissolved in $\mathrm{CH}_{2} \mathrm{Cl}_{2}(5 \mathrm{~mL})$ over 30 min. After $5 \mathrm{~h}, \mathrm{NaHCO}_{3(\mathrm{aq})}$ was added. After a conventional workup, flash chromatography (petroleum ether:diethyl ether, 20:1) afforded product 8a (183 mg, 62\%); a subsequent fraction contained $3 \mathbf{b}(50 \mathrm{mg}, 16.7 \%)$. 8a: IR (neat, $\mathrm{NaCl}) v_{\max } 3033,2928,2087,2040$, $1642 \mathrm{~cm}^{-1} ;{ }^{1} \mathrm{H}$ NMR $\delta$ 7.27-7.39 (m, 5H), $5.89(\mathrm{~m}, 1 \mathrm{H}), 5.14(\mathrm{dd}, \mathrm{J}=1.5,15.6,1 \mathrm{H}), 5.08$ $(\mathrm{dd}, \mathrm{J}=1.5,10.2,1 \mathrm{H}), 4.72(\mathrm{~s}, 2 \mathrm{H}), 4.68(\mathrm{~s}, 2 \mathrm{H}), 4.64(\mathrm{~s}, 2 \mathrm{H}), 2.95(\mathrm{t}, \mathrm{J}=8.0,2 \mathrm{H}), 2.40(\mathrm{~m}, 2 \mathrm{H})$; ${ }^{13}$ C NMR 199.6, 137.8, 136.8, 128.4, 127.8, 127.5, 116.0, 93.8, 93.6, 93.5, 92.6, 73.1, 69.8, 41.2, 
35.6, 32.8; MS (EI $\left.{ }^{+}\right) \mathrm{m} / \mathrm{e} 726(\mathrm{M}-3 \mathrm{CO})^{+}, 586(\mathrm{M}-8 \mathrm{CO})^{+}$; MS (LSIMS) m/e $726(\mathrm{M}-3 \mathrm{CO})^{+}, 642(\mathrm{M}-$ $6 \mathrm{CO})^{+}$.

From 3a: To a solution of complex 3a (200 mg, $0.25 \mathrm{mmol})$ in $\mathrm{CH}_{2} \mathrm{Cl}_{2}(15 \mathrm{~mL})$ was condensed with nucleophile $7 \mathbf{b}(166 \mathrm{mg}, 0.50 \mathrm{mmol})$ in the presence of $\mathrm{BF}_{3}-\mathrm{Et}_{2} \mathrm{O}(71 \mathrm{mg}, 0.50 \mathrm{mmol}, 2$ equiv) according to the general procedure. After flash chromatography (petroleum ether.diethyl ether, 20:1), 8a (127 mg, 63\%) was obtained, followed by $\mathbf{3 a}(47 \mathrm{mg}, 23.5 \%)$.

From 3a and 7a: The reaction of the complex 3a (200 mg, $0.25 \mathrm{mmol})$ with $7 \mathbf{a}(79 \mu \mathrm{L}, 57 \mathrm{mg}, 0.50$ mmol) in the presence of $\mathrm{BF}_{3}-\mathrm{Et}_{2} \mathrm{O}$ ( $36 \mathrm{mg}, 0.25 \mathrm{mmol}, 1$ equiv) according to the general procedure. After flash chromatography (petroleum ether:diethyl ether, 20:1), 8a (79 mg, 39\%) was obtained, followed by $\mathbf{3 a}(102 \mathrm{mg}, 51 \%)$.

\section{Dodecacarbonyl $\left[\mu^{4}-(\eta, \eta, \eta, \eta)(1-b e n z y l o x y-8-m e t h y l-9-0 x 0-9-p h e n y l-2,5-n o n a d i y n e)\right]$}

tetracobalt (2 Co-Co) (8b). Complex $\mathbf{3 b}(300 \mathrm{mg}, 0.36 \mathrm{mmol})$ was reacted with the nucleophile $7 \mathbf{c}(150 \mathrm{mg}, 0.72 \mathrm{mmol})$ in the presence of $\mathrm{BF}_{3}-\mathrm{Et}_{2} \mathrm{O}(51 \mathrm{mg}, 0.36 \mathrm{mmol})$ via the general procedure. Flash chromatography (petroleum ether:diethyl ether, 10:1) afforded $\mathbf{8 b}$ (208 mg, 64\%): IR (neat, $\mathrm{NaCl}) v_{\max } 3033,2934,2085,2063,1990,1683 \mathrm{~cm}^{-1} ;{ }^{1} \mathrm{H}$ NMR $\delta 8.04$ (d, J = 7.7, 2H), 7.27-7.59 (m, 8H), $4.76(\mathrm{~s}, 2 \mathrm{H}), 4.75(\mathrm{~s}, 2 \mathrm{H}), 4.58(\mathrm{~d}, \mathrm{~J}=4.8,2 \mathrm{H}), 3.74(\mathrm{~m}, 1 \mathrm{H}), 3.71$ $(1 / 2 \mathrm{AB}, \mathrm{J}=11.7,1 \mathrm{H}), 2.93(1 / 2 \mathrm{AB}, \mathrm{J}=11.7,1 \mathrm{H}), 1.37(\mathrm{~d}, \mathrm{~J}=6.7,3 \mathrm{H}) ;{ }^{13} \mathrm{C}$ NMR 201.7, 199.6, 137.9, 135.5, 133.3, 128.7, 128.3, 127.6, 127.5, 127.4, 97.3, 93.9, 93.0, 91.0, 73.0, 69.8, 43.1, 41.0, 36.1, 19.4; MS (EI) m/e $818(\mathrm{M}-3 \mathrm{CO})^{+}, 762(\mathrm{M}-5 \mathrm{CO})^{+}$; (LSIMS) m/e $819(\mathrm{M}+1-3 \mathrm{CO})^{+}$, $763(\mathrm{M}+1-5 \mathrm{CO})^{+}, 735(\mathrm{M}+1-6 \mathrm{CO})^{+}$. A subsequent fraction contained $\mathbf{3 b}(27 \mathrm{mg}, 9 \%)$.

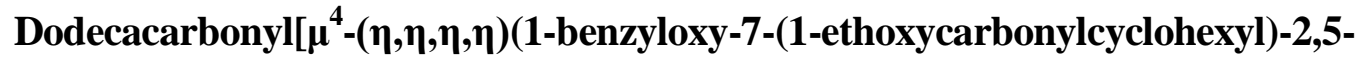
heptadiyne)]tetracobalt (2 Co-Co) (8c). Compound $\mathbf{3 b}$ was (300 $\mathrm{mg}, 0.36 \mathrm{mmol}$ ) reacted with nucleophile $7 \mathbf{d}(150 \mathrm{mg}, 0.72 \mathrm{mmol})$ in the presence of $\mathrm{BF}_{3}-\mathrm{Et}_{2} \mathrm{O}(51 \mathrm{mg}, 0.36 \mathrm{mmol})$ according to 
the general procedure. Flash chromatography (petroleum ether:diethyl ether, 15:1) afforded product 8c (210 mg, 63\%); IR (neat, $\mathrm{NaCl}) v_{\max } 3033,2935,2094,2086,2022,1730 \mathrm{~cm}^{-1} ;{ }^{1} \mathrm{H}$ NMR $\delta$ 7.27-7.39 (m, 5H), $4.73(\mathrm{~s}, 2 \mathrm{H}), 4.70(\mathrm{~s}, 2 \mathrm{H}), 4.60(\mathrm{~s}, 2 \mathrm{H}), 4.20(\mathrm{q}, \mathrm{J}=7.0,2 \mathrm{H}), 3.23(\mathrm{~s}, 2 \mathrm{H})$, 1.25-2.17 (m, 13H); ${ }^{13} \mathrm{C}$ NMR 199.7, 175.4, 137.8, 128.4, 127.7, 127.5, 95.2, 93.0, 92.9, 90.9, 73.0, 69.7, 60.6, 48.1, 41.0, 34.6, 25.5, 22.8, 14.0; MS (EI) m/e $840(\mathrm{M}-3 \mathrm{CO})^{+}, 700(\mathrm{M}-7 \mathrm{CO})^{+}$; (LSIMS) m/e $840(\mathrm{M}-3 \mathrm{CO})^{+}, 728(\mathrm{M}-6 \mathrm{CO})^{+}$. A subsequent fraction contained $\mathbf{3 b}(28 \mathrm{mg}, 9 \%)$.

\section{Dodecacarbonyl $\left[\mu^{4}-(\eta, \eta, \eta, \eta)(1-b e n z y l o x y-7-(2-o x o c y c l o h e x y l)-2,5-h e p t a d i y n e)\right]$ tetracobalt $(2$}

Co-Co) (8d). Complex 3b (200 mg, $0.24 \mathrm{mmol})$ was condensed with the nucleophile 7e (86 mg, $0.29 \mathrm{mmol})$ in the presence of $\mathrm{BF}_{3}-\mathrm{Et}_{2} \mathrm{O}(51 \mathrm{mg}, 0.36 \mathrm{mmol})$ via the general procedure. Flash chromatography (petroleum ether:diethyl ether, 10:1) afforded $\mathbf{8 d}(85 \mathrm{mg}, 41 \%)$ : IR (neat, $\mathrm{NaCl}$ ) $\mathrm{v}_{\max } 3033,2933,2085,2022,1716 \mathrm{~cm}^{-1}$; 'H NMR $\delta 7.27-7.39(\mathrm{~m}, 5 \mathrm{H}), 4.75(\mathrm{~s}, 2 \mathrm{H}), 4.72(\mathrm{~s}$, 2H), 4.64 (s, 2H), 3.58 (m, $1 \mathrm{H}), 1.49-2.60$ (m, 10H); ${ }^{13} \mathrm{C}$ NMR 210.9, 199.6, 137.9, 128.3, 127.6, 127.5, 98.1, 93.6, 92.9, 91.1, 73.0, 69.8, 53.4, 42.0, 41.2, 35.4, 32.8, 28.2, 25.3; MS (EI) m/e $782(\mathrm{M}-3 \mathrm{CO})^{+}, 642(\mathrm{M}-8 \mathrm{CO})^{+}$; (LSIMS) m/e $782(\mathrm{M}-3 \mathrm{CO})^{+}, 698(\mathrm{M}-6 \mathrm{CO})^{+}$. A subsequent fraction contained $\mathbf{3 b}(54 \mathrm{mg}, 27 \%)$.

From 3a: The complex 3a (300 mg, $0.37 \mathrm{mmol})$ also reacted with the nucleophile 7e (78 $\mathrm{mg}$, $0.44 \mathrm{mmol})$ in the presence of $\mathrm{BF}_{3}-\mathrm{Et}_{2} \mathrm{O}(54 \mathrm{mg}, 0.38 \mathrm{mmol})$ via the general procedure. Flash chromatography afforded 8d (141 mg, 43\%), followed by 3a (130 mg, 43\%).

Dodecacarbonyl $\left[\mu^{4}-(\eta, \eta, \eta, \eta)(t\right.$ trideca-1,12-dien-5,8-diyne $\left.)\right]$ tetracobalt $(2$ Co-Co) (9a).

Complex 3a (200 mg, $0.25 \mathrm{mmol})$ was condensed with nucleophile $7 \mathbf{b}$ (331 mg, $1.00 \mathrm{mmol})$ in the presence of $\mathrm{BF}_{3}-\mathrm{Et}_{2} \mathrm{O}(142 \mathrm{mg}, 1.00 \mathrm{mmol})$ via the general procedure. Flash chromatography (petroleum ether:diethyl ether, 10:1) afforded 9a (127 mg, 73\%): IR (neat, $\mathrm{NaCl}) v_{\max } 3085,2941,2093,2022,1643 \mathrm{~cm}^{-1} ;{ }^{1} \mathrm{H}$ NMR $\delta 5.94$ (m, 2H), $5.17(\mathrm{dd}, \mathrm{J}=1.4 \mathrm{~Hz}$, 
17.2, 2H), $5.10(\mathrm{dd}, \mathrm{J}=1.4,10.0,2 \mathrm{H}), 4.65(\mathrm{~s}, 4 \mathrm{H}), 2.99(\mathrm{t}, \mathrm{J}=7.9,4 \mathrm{H}), 2.40(\mathrm{~m}, 2 \mathrm{H}) ;{ }^{13} \mathrm{C}$ NMR 199.9, 136.8, 116.0, 98.5, 92.6, 41.4, 35.6, 32.8; MS (EI) $716(\mathrm{M}-1 \mathrm{CO})^{+}, 688(\mathrm{M}-2 \mathrm{CO})^{+}$; (LSIMS) m/e $716(\mathrm{M}-1 \mathrm{CO})^{+}, 604(\mathrm{M}-5 \mathrm{CO})^{+}$. A subsequent fraction contained $\mathbf{8 b}(27.0 \mathrm{mg}$, $12 \%)$

Under directly analogous conditions, the reaction of complex $\mathbf{3 a}(200 \mathrm{mg}, 0.25 \mathrm{mmol})$ with $7 \mathbf{a}$ $(0.16 \mathrm{~mL}, 1.0 \mathrm{mmol})$ and $\mathrm{BF}_{3}-\mathrm{OEt}_{2}(142 \mathrm{mg}, 1.00 \mathrm{mmol})$ afforded product $9 \mathrm{a}(170 \mathrm{mg}, 90 \%)$.

Dodecacarbonyl $\left[\mu^{4}-(\eta, \eta, \eta, \eta)(2,10-d i m e t h y l-1,11-d i p h e n y l u n d e c a-4,7-d i y n-1,11-\right.$ dione)]tetracobalt (2 Co-Co) (9b) Complex 3b $(75.1 \mathrm{mg}, 0.0907 \mathrm{mmol}$ ) was condensed with 7c (74.9mg, $0.363 \mathrm{mmol})$ in the presence of $\mathrm{BF}_{3}-\mathrm{OEt}_{2}(46 \mu \mathrm{L}, 0.36 \mathrm{mmol})$ via the general procedure. Flash chromatography (petroleum ether:diethyl ether 10:1) gave $\mathbf{9 b}(59.0 \mathrm{mg}, 70 \%)$ as a 1:1 diastereomeric mixture: IR (neat, $\mathrm{NaCl}$ ) $v_{\max } 2093,2084,2051,2017,1683 \mathrm{~cm}^{-1} ;{ }^{1} \mathrm{H}$ NMR $\delta 8.03(\mathrm{~d}, \mathrm{~J}=8.0,4 \mathrm{H}), 7.57(\mathrm{t}, \mathrm{J}=7.6,2 \mathrm{H}), 7.48$ (apparent $\mathrm{t}, \mathrm{J}=7.7,4 \mathrm{H}), 4.56+4.46(\mathrm{AB}$, $\mathrm{J}=18.1)$ and $4.52(\mathrm{~s})(2 \mathrm{H}), 3.73-3.81(\mathrm{~m}, 4 \mathrm{H}), 2.91-3.03(\mathrm{~m}, 2 \mathrm{H}), 1.41(\mathrm{~d}, \mathrm{~J}=6.5)$ and 1.39 $(\mathrm{d}, \mathrm{J}=6.5)(6 \mathrm{H}) ;{ }^{13} \mathrm{C}$ NMR 201.7, 199.9 and 199.5, 135.5, 133.29 and 133.28, 128.8, 128.4, 97.4 and 97.3, 93.9 and 93.8, 43.1, 41.0 and 40.9 36.0, 19.6 and 19.4; MS (EI) m/e $844(\mathrm{M}-3 \mathrm{CO})^{+}$, $648(\mathrm{M}-10 \mathrm{CO})^{+} ;(\mathrm{LSIMS}) \mathrm{m} / \mathrm{e} 929(\mathrm{M}+1)^{+}, 844(\mathrm{M}-3 \mathrm{CO})^{+}$.

Dodecacarbonyl $\left[\mu^{4}-(\eta, \eta, \eta, \eta)(1-(2,4,6\right.$-trimethoxyphenyl)deca-9-en-2,5-diyne)]tetracobalt (2 Co-Co) (10a). Compound $8 \mathbf{a}$ ( $240 \mathrm{mg}, 0.30 \mathrm{mmol})$ was condensed with 1,3,5trimethoxybenzene (7f) $(101 \mathrm{mg}, 0.60 \mathrm{mmol})$ in the presence of $\mathrm{BF}_{3}-\mathrm{Et}_{2} \mathrm{O}(85 \mathrm{mg}, 0.60 \mathrm{mmol})$ via the general procedure. Flash chromatography (petroleum ether diethyl ether, 20:1) afforded 10a (245 mg, 95\%): IR (neat, $\mathrm{NaCl}) v_{\max } 3007,2942,2082,2045,2022,1615 \mathrm{~cm}^{-1} .{ }^{1} \mathrm{H}$ NMR: $\delta$ $6.14(\mathrm{~s}, 2 \mathrm{H}), 5.95(\mathrm{~m}, 1 \mathrm{H}), 5.18(\mathrm{dd}, \mathrm{J}=1.5,17.0,1 \mathrm{H}), 5.08(\mathrm{dd}, \mathrm{J}=1.5,10.0,1 \mathrm{H}), 4.59(\mathrm{~s}, 2 \mathrm{H})$, 4.17 (s, 2H), 3.81 (s, 3H), 3.77 (s, 6H), $3.06(\mathrm{t}, \mathrm{J}=8.1,2 \mathrm{H}), 2.45(\mathrm{~m}, 2 \mathrm{H}) ;{ }^{13} \mathrm{C}$ NMR 199.9, 
$160.5,158.7,136.9,115.8,108.2,100.2,98.4,93.5,92.8,89.9,55.3,54.7,41.2,35.6,32.8,26.0$;

MS (EI) $842(\mathrm{M}-1 \mathrm{CO})^{+}, 786(\mathrm{M}-3 \mathrm{CO})^{+}$; (LSIMS) m/e $767(\mathrm{M}-3 \mathrm{CO})^{+}, 730(\mathrm{M}-5 \mathrm{CO})^{+}$.

Dodecacarbonyl $\left[\mu^{4}-(\eta, \eta, \eta, \eta)(1-(1-c a r b o e t h o x y c y c l o h e x y l)-d e c-9-e n-2,5-d i y n e)\right]$ tetracobalt

(2 Co-Co) (10b) Compound $8 \mathbf{c}(109.8 \mathrm{mg}, 0.119 \mathrm{mmol})$ was reacted with allyltrimethylsilane

(38 $\mu \mathrm{L}, 0.24 \mathrm{mmol})$ and $\mathrm{BF}_{3}-\mathrm{OEt}_{2}(30 \mu \mathrm{L}, 0.24 \mathrm{mmol})$ via the standard procedure. Flash

chromatography (25:1 petroleum ether:diethyl ether) afforded $\mathbf{1 0 b}(77.6 \mathrm{mg}, 76 \%)$, as a red-

brown oil: IR (neat, KBr) $v_{\max }$ 2094, 2084, 2048, 2014, $1728 \mathrm{~cm}^{-1} .{ }^{1} \mathrm{H}$ NMR: $\delta 5.95(\mathrm{~m}, 1 \mathrm{H})$,

$5.17(\mathrm{~d}, \mathrm{~J}=17.1,1 \mathrm{H}), 5.10(\mathrm{~d}, \mathrm{~J}=10.3,1 \mathrm{H}), 4.60(\mathrm{~s}, 2 \mathrm{H}), 4.21(\mathrm{q}, \mathrm{J}=7.1,2 \mathrm{H}), 3.27(\mathrm{~s}, 2 \mathrm{H})$,

$2.95-3.05(\mathrm{~m}, 2 \mathrm{H}), 2.38-2.50(\mathrm{~m}, 2 \mathrm{H}), 2.12-2.30(\mathrm{~m}, 2 \mathrm{H}), 1.20-1.75(\mathrm{~m}, 8 \mathrm{H}), 1.28(\mathrm{t}, \mathrm{J}=$

7.1, 3H); ${ }^{13}$ C NMR 199.9, 199.8, 175.4, 136.8, 115.8, 98.5, 95.2, 92.8, 92.6, 60.6, 48.1, 43.8,

41.2, 35.6, 34.6, 32.5, 29.7, 25.6, 22.8, 14.0; MS (EI) $774(\mathrm{M}-3 \mathrm{CO})^{+}, 718(\mathrm{M}-5 \mathrm{CO})^{+;}(\mathrm{LSIMS})$

$\mathrm{m} / \mathrm{e} 774(\mathrm{M}-3 \mathrm{CO})^{+}, 718(\mathrm{M}-5 \mathrm{CO})^{+}, 690(\mathrm{M}-6 \mathrm{CO})^{+}$.

Synthesis of Dodecacarbonyl $\left[\mu^{4}-(\eta, \eta, \eta, \eta)(1-b e n z y l o x y-7-h y d r o x y-2,5-\right.$

undecadiyne)]tetracobalt

(2 Co-Co) (11). To a solution of freshly prepared 6-benzyloxy-1,4-hexadiyne (4) (56.4 mg, 3.06 $\mathrm{mmol})$ in THF at $-78^{\circ} \mathrm{C}$ was added methyllithium $(3.06 \mathrm{~mL}, 1.5 \mathrm{M}, 4.59 \mathrm{mmol})$. The mixture was stirred for $20 \mathrm{~min}$ and freshly distilled of pentanal $(651 \mu \mathrm{L}, 6.12 \mathrm{mmol})$ was added dropwise. After stirring for $3 \mathrm{~h}$, the reaction mixture diluted with cold water at $0{ }^{\circ} \mathrm{C}$. Following a conventional workup, the crude product was diluted with diethyl ether and placed in an ice bath. An excess amount of cobalt carbonyl was added and the mixture stirred for $3.5 \mathrm{~h}$. Following removal of the volatiles under reduced pressure, flash chromatography (20:1 petroleum ether : diethyl ether) gave (11) $(90.2 \mathrm{mg}, 44 \%)$ as red-brown oil: IR (neat) $v_{\max } 3386,2919,2012 \mathrm{~cm}^{-1}$;

${ }^{1} \mathrm{H}$ NMR $\delta 7.32(\mathrm{~m}, 5 \mathrm{H}), 4.68(\mathrm{~m}, 7 \mathrm{H}), 2.79(\mathrm{~d}, \mathrm{~J}=5.2,1 \mathrm{H}), 1.64(\mathrm{~m}, 3 \mathrm{H}), 1.36(\mathrm{~m}, 3 \mathrm{H}), 0.92(\mathrm{t}$, 
$\mathrm{J}=7.1,3 \mathrm{H}) .{ }^{13} \mathrm{C}$ NMR 199.6, 199.3, 137.0, 128.5, 128.1, 128.0, 102.4, 92.0, 91.3, 91.0, 73.4, 71.5, 70.1, 41.2, 39.2, 28.5, 22.4, 13.9; MS (EI) m/e: $758(\mathrm{M}-3 \mathrm{CO})^{+}, 618(\mathrm{M}-8 \mathrm{CO})^{+}$; (LSIMS) m/e: $757(\mathrm{M}-1-3 \mathrm{CO})^{+}, 617(\mathrm{M}-1-8 \mathrm{CO})^{+}$.

Dodecacarbonyl $\left[\mu^{4}-(\eta, \eta, \eta, \eta)(1-b e n z y l o x y-2,5-\right.$ undecadiyne) $]$ tetracobalt $(2$ Co-Co) (13). To a solution of (11) (353 mg, $0.41 \mathrm{mmol})$ and $\mathrm{Ph}_{3} \mathrm{SnH}(220 \mathrm{mg}, 0.62 \mathrm{mmol})$ in $\mathrm{CH}_{2} \mathrm{Cl}_{2}(10 \mathrm{~mL})$ at 5 ${ }^{\circ} \mathrm{C}$ was added $\mathrm{BF}_{3}-\mathrm{Et}_{2} \mathrm{O}(53 \mu \mathrm{L}, 0.41 \mathrm{mmol})$. After stirring for $20 \mathrm{~h}$ with regular monitoring by TLC, the reaction mixture was diluted with water and subjected to conventional work up. Flash chromatography (100:1 petroleum ether : diethyl ether) afforded (13) as a red-brown oil (290 mg, 84\%): IR (neat) $v_{\max } 2933,2099 \mathrm{~cm}^{-1} ;{ }^{1} \mathrm{H}$ NMR $\delta \square 7.35$ (m, 5H), 4.74 (s, 2H), 4.70 (s, 2H), $4.65(\mathrm{~s}, 2 \mathrm{H}), 2.84(\mathrm{t}, \mathrm{J}=8.0,2 \mathrm{H}), 1.66(\mathrm{~m}, 2 \mathrm{H}), 1.41(\mathrm{~m}, 4 \mathrm{H}), 0.95(\mathrm{t}, \mathrm{J}=7.0,3 \mathrm{H}):{ }^{13} \mathrm{C}$ NMR 200.0, 199.5, 137.8, 128.3, 127.7, 127.4, 99.7, 93.0, 92.5, 91.1, 73.0, 69.7, 41.2, 33.3, 31.6, 31.5, 22.3, 13.8; MS (EI) m/e: $742(\mathrm{M}-3 \mathrm{CO})^{+}, 658(\mathrm{M}-6 \mathrm{CO})^{+}$; (ES-) m/e: $768.5(\mathrm{M}-2 \mathrm{CO}-\mathrm{H})^{-}, 740.5$ $(\mathrm{M}-3 \mathrm{CO}-\mathrm{H})^{-}$.

(1'R, 2'S, 5'R)- 1-Menthoxy-2,5-heptadiyne (15). To a solution freshly prepared solution of EtMgBr (15.0 mmol) in dry THF (20 mL) was added 3-menthyloxy-1-propyne (14) (1.464 g, $7.53 \mathrm{mmol}$ ) in cannula under a stream of nitrogen. The solution was heated for $30 \mathrm{~min}$ at $60{ }^{\circ} \mathrm{C}$ and cooled to room temperature. $\mathrm{CuCl}$ was added $(74 \mathrm{mg}, 0.75 \mathrm{mmol}$ ), followed by propargyl bromide $(1.67 \mathrm{~mL}, 18.0 \mathrm{mmol})$. The solution was heated to reflux for $1 \mathrm{~h}$. A conventional work up and subsequent flash chromatography (100\% hexane) afforded (15) $(1.313 \mathrm{~g}, 75 \%)$ as a colorless oil: $[\alpha]^{25}{ }_{D}^{-66.9}$ (c 1.17 acetone); IR (neat) $\mathrm{v}_{\max } 3312,2954,2869 \mathrm{~cm}^{-1} ;{ }^{1} \mathrm{H}$ NMR $\delta \square$ $4.16(t$ of $1 / 2 \mathrm{AB}, \mathrm{J}=2.0,15.5,1 \mathrm{H}), 4.11(\mathrm{t}$ of $1 / 2 \mathrm{AB}, \mathrm{J}=1.9,15.5,1 \mathrm{H}), 3.16(\mathrm{~m}, 3 \mathrm{H}), 2.18(\mathrm{~m}$, 1H), $2.03(\mathrm{~m}, 1 \mathrm{H}), 1.57(\mathrm{~m}, 2 \mathrm{H}), 1.57(\mathrm{~m}, 1 \mathrm{H}), 1.34(\mathrm{~m}, 1 \mathrm{H}), 0.70-1.00(\mathrm{~m}, 4 \mathrm{H}), 0.87(\mathrm{~d}, \mathrm{~J}=$ 6.6, 3H), $0.84(\mathrm{~d}, \mathrm{~J}=7.1,3 \mathrm{H}), 0.74(\mathrm{~d}, \mathrm{~J}=6.9,3 \mathrm{H}) ;{ }^{13} \mathrm{C}$ NMR 78.5, 77.78, 77.74, 77.72, 68.8, 
55.4, 48.0, 39.7, 34.3, 31.3, 25.2, 23.1, 22.2, 20.9, 16.0, 9.5. MS (EI) m/e: $232(\mathrm{M})^{+}$; HRMS calc for $\mathrm{C}_{16} \mathrm{H}_{24} \mathrm{O}$ 232.1827, found 232.1826.

$\left(1^{\prime} R, 2^{\prime} S, 5^{\prime} R\right)-$ Dodecacarbonyl $\left[\mu^{4}-(\eta, \eta, \eta, \eta)(1-m e n t h o x y-7-m e t h o x y-2,5-\right.$ heptadiyne)]tetracobalt (2 Co-Co) (16)

To a solution of (15) $(1.75 \mathrm{~g}, 7.50 \mathrm{mmol})$ in diethyl ether $(20 \mathrm{~mL})$ at $-78{ }^{\circ} \mathrm{C}$ and was added MeLi (8.0 mL, 1.40 M, $11.2 \mathrm{mmol}$ ). The solution was then stirred for $20 \mathrm{~min}$, and chloromethyl methyl ether $(1.13 \mathrm{~mL}, 15.0 \mathrm{mmol})$ was added. The reaction mixture was allowed to warm up to room temperature and stirred overnight. Following a conventional work up, the resulting crude product was dissolved in anhydrous $\mathrm{Et}_{2} \mathrm{O}(20 \mathrm{~mL})$ and cooled to $0{ }^{\circ} \mathrm{C}$. An excess of cobalt carbonyl was added and the solution stirred for $3.5 \mathrm{~h}$. The resulting crude product was filtered though Celite ${ }^{\circledR} \square$ and the resulting filtrate was concentrated under reduced pressure. Flash chromatography (petroleum ether: diethyl ether, 50:1) gave (16) $(3.946 \mathrm{~g}, 72 \%)$ as a red-brown oil: $[\alpha]^{22}+72(\mathrm{c}$ 0.036 acetone); IR (neat) $\mathrm{v}_{\max } 2923,2052 \mathrm{~cm}^{-1} ;{ }^{1} \mathrm{H}$ NMR $\delta \square 4.8(\mathrm{~d}, \mathrm{~J}=12.5,1 \mathrm{H}), 4.6(\mathrm{~m}, 4 \mathrm{H})$, $4.51(\mathrm{~d}, \mathrm{~J}=12.5,1 \mathrm{H}), 3.52(\mathrm{~s}, 3 \mathrm{H}), 3.26$ (apparent dt, J = 4.1, 10.5, 1H), $2.31(\mathrm{~m}, 1 \mathrm{H}), 2.14(\mathrm{~d}, \mathrm{~J}$ $=12.0,1 \mathrm{H}), 1.67(\mathrm{~m}, 2 \mathrm{H}), 1.41(\mathrm{~m}, 1 \mathrm{H}), 1.31(\mathrm{~m}, 1 \mathrm{H}), 0.88-1.10(\mathrm{~m}, 3 \mathrm{H}), 0.96(\mathrm{~d}, \mathrm{~J}=6.0,3 \mathrm{H})$, $0.90(\mathrm{~d}, \mathrm{~J}=7.0,3 \mathrm{H}), 0.80(\mathrm{~d}, \mathrm{~J}=6.9,3 \mathrm{H}) ;{ }^{13} \mathrm{C} \mathrm{NMR} 199.7,94.7,92.7,91.6,90.7,79.3,72.6$, 67.8, 58.8, 48.2, 41.0, 40.3, 34.5, 31.6, 25.3, 23.1, 22.3, 20.8, 15.9; MS (EI) m/e 820 (M-CO) ${ }^{+}$, $596(\mathrm{M}-9 \mathrm{CO})^{+} ;(\mathrm{ES}+) \mathrm{m} / \mathrm{e} 691(\mathrm{M}+\mathrm{K}-7 \mathrm{CO})^{+}$.

$\left(1^{\prime} R, 2^{\prime} S, 5^{\prime} R\right)$ - Dodecacarbonyl $\left[\mu^{4}-(\eta, \eta, \eta, \eta)(1-m e n t h o x y d e c a-9-e n-2,5-d i y n e)\right]$ tetracobalt (2 Co-Co) (18a)

To a solution of (16) $(207 \mathrm{mg}, 0.244 \mathrm{mmol})$ in $\mathrm{CH}_{2} \mathrm{Cl}_{2}(5 \mathrm{~mL})$ at $0{ }^{\circ} \mathrm{C}$ was added $\mathrm{BF}_{3} . \mathrm{Et}_{2} \mathrm{O}(144$ $\mu \mathrm{L}, 1.14 \mathrm{mmol})$. The solution stirred for $10 \mathrm{~min}$; thereafter, allyltrimethysilane $(67 \mu \mathrm{L}, 0.42$ mmol) was added and the reaction was continued until none of the starting $\mathbf{1 6}$ was detected in 
TLC analysis (12 h). A conventional work up and subsequent flash chromatography (100\% petroleum ether) afforded (18a) $(148 \mathrm{mg}, 71 \%)$ as a red-brown oil: : $[\alpha]^{22}{ }_{\mathrm{D}}+52(\mathrm{c} 0.079$ acetone) IR (neat) $v_{\max } 2924,2085,2049 \mathrm{~cm}^{-1} ;{ }^{1} \mathrm{H}$ NMR $\delta \square 5.94(\mathrm{~m}, 1 \mathrm{H}), 5.17(\mathrm{~d}, \mathrm{~J}=17.0,1 \mathrm{H})$, $5.10(\mathrm{~d}, \mathrm{~J}=12.1,1 \mathrm{H}), 4.82(\mathrm{~d}, \mathrm{~J}=12.4,1 \mathrm{H}), 4.65(\mathrm{~s}, 2 \mathrm{H}), 4.50(\mathrm{~d}, \mathrm{~J}=12.4,1 \mathrm{H}), 3.24$ (apparent $\mathrm{dt}, \mathrm{J}=4.0,10.5,1 \mathrm{H}), 2.99(\mathrm{~m}, 2 \mathrm{H}), 2.42(\mathrm{~m}, 2 \mathrm{H}), 2.29(\mathrm{~m}, 1 \mathrm{H}), 2.11(\mathrm{br} \mathrm{d}, \mathrm{J}=12.11 \mathrm{H}), 1.63$ (m, 2H), $1.30(\mathrm{~m}, 1 \mathrm{H}), 1.28(\mathrm{~m}, 1 \mathrm{H}), 0.85-1.17(\mathrm{~m}, 3 \mathrm{H}), 0.95(\mathrm{~d}, \mathrm{~J}=6.4,3 \mathrm{H}), 0.89(\mathrm{~d}, \mathrm{~J}=7.0$, 3H), $0.78(\mathrm{~d}, \mathrm{~J}=7.0,3 \mathrm{H}) ;{ }^{13} \mathrm{C}$ NMR 199.7, 136.8, 115.9, 98.5, 94.6, 92.9, 90.5, 79.3, 67.8, 48.2, $41.2,40.2,35.5,34.5,32.8,31.6,25.4,23.1,22.3,20.8,15.9 ; \mathrm{MS}(\mathrm{EI}) \mathrm{m} / \mathrm{e} 802(\mathrm{M}-2 \mathrm{CO})^{+}, 774$ $(\mathrm{M}-3 \mathrm{CO})^{+} ;(\mathrm{ES}+) \mathrm{m} / \mathrm{e} 795\left(\mathrm{M}-3 \mathrm{CO}+\mathrm{Na}-\mathrm{H}_{2}\right)^{+}, 688\left(\mathrm{M}-6 \mathrm{CO}+\mathrm{Na}-\mathrm{H}_{2}\right)^{+}$.

\section{$\left(1 ' R, 2^{\prime} S, 5^{\prime} R\right)$ - Dodecacarbonyl[ $\mu^{4}-(\eta, \eta, \eta, \eta)(1-m e n t h o x y-7-(2-0 x o c y c l o h e x y l)-2,5-$}

heptadiyne)]tetracobalt (2 Co-Co)(18b) To a solution of (16) $(90 \mathrm{mg}, 0.12 \mathrm{mmol})$ and the trimethylsilyl enol ether of cyclohexenone (7e) $(62 \mathrm{mg}, 0.36 \mathrm{mmol})$ in $\mathrm{CH}_{2} \mathrm{Cl}_{2}(5 \mathrm{~mL})$ at $0{ }^{\circ} \mathrm{C}$ was added $\mathrm{Bu}_{2} \mathrm{BOTf}(73 \mu \mathrm{L}, 1 \mathrm{M})$. The solution was stirred for $3 \mathrm{~h}$, and further $\mathrm{Bu}_{2} \mathrm{BOTf}$ (74 $\mu \mathrm{L}, 1 \mathrm{M})$ was added; stirring was continued until none of the starting $\mathbf{1 6}$ was detected in TLC analysis (12 h) (total amount $\mathrm{Bu}_{2} \mathrm{BOTf}$ used $147 \mu \mathrm{L}, 0.14 \mathrm{mmol}$ ). A conventional work up and subsequent flash chromatography (100\% petroleum ether) afforded $(\mathbf{1 8 b})(70 \mathrm{mg}, 71 \%$, de $=0)$ as a red brown oil: IR (neat) $v_{\max } 2929,2869,2085,2053 \mathrm{~cm}^{-1} ;{ }^{1} \mathrm{H}$ NMR $\delta \square 4.851(\mathrm{~d}, \mathrm{~J}=12.5)$ and $4.847(\mathrm{~d}, \mathrm{~J}=12.5)(1 \mathrm{H}), 4.61(\mathrm{~m}, 2 \mathrm{H}), 4.53(\mathrm{~d}, \mathrm{~J}=12.5)$ and $4.52(\mathrm{~d}, \mathrm{~J}=12.5)(1 \mathrm{H}), 3.59$ (dd, J = 6.5, 15.5, 1H), 3.24 (apparent dt, J = 4.1, 10.5, 1H), $2.59(\mathrm{~m}, 2 \mathrm{H}), 2.45(\mathrm{~m}, 1 \mathrm{H}), 2.38(\mathrm{~m}$, 1H), $2.27(\mathrm{~m}, 2 \mathrm{H}), 2.12(\mathrm{~m}, 2 \mathrm{H}), 1.92(\mathrm{~m}, 1 \mathrm{H}), 1.65(\mathrm{~m}, 6 \mathrm{H}),(\mathrm{m}, 1 \mathrm{H}), 0.85-1.15(\mathrm{~m}, 3 \mathrm{H}), 0.95$ $(\mathrm{d}, \mathrm{J}=6.6,3 \mathrm{H}), 0.88(\mathrm{~d}, \mathrm{~J}=6.9,3 \mathrm{H}), 0.77(\mathrm{~d}, \mathrm{~J}=7.2,3 \mathrm{H}) .{ }^{13} \mathrm{C}$ NMR 211.0, 199.8, 98.0, 94.7, $94.6,93.8,90.4,79.3,79.2,67.7,53.4,48.2,42.1,40.2,35.6,35.5,34.5,32.7,31.6,28.2,25.4$, 
23.1, 22.3, 20.9, 15.9; MS (EI+) m/e: $830(\mathrm{M}-3 \mathrm{CO})^{+}, 718(\mathrm{M}-7 \mathrm{CO})^{+}$; (ES+) m/e: $937(\mathrm{M}+$ $\mathrm{Na})^{+}, 909(\mathrm{M}+\mathrm{Na}-\mathrm{CO})^{+}$.

Dodecacarbonyl $\left[\mu^{4}-(\eta, \eta, \eta, \eta)(1-m e t h o x y d e c a-9-e n-2,5-d i y n e)\right]$ tetracobalt (2 Co-Co) (19)

To a solution of (18a) $(122 \mathrm{mg}, 0.16 \mathrm{mmol})$ in $\mathrm{CH}_{2} \mathrm{Cl}_{2}(5 \mathrm{~mL})$ at $0{ }^{\circ} \mathrm{C}$ was added $\mathrm{BF}_{3}-\mathrm{Et}_{2} \mathrm{O}(83$ $\mu \mathrm{L}, 0.65 \mathrm{mmol})$. The solution was stirred for $10 \mathrm{~min}$, and $\mathrm{MeOH}(20 \mu \mathrm{L}, 0.49 \mathrm{mmol})$ was added. After stirring for $12 \mathrm{~h}$, the crude reaction mixture was subjected to conventional work up. Flash chromatography (100\% petroleum ether) afforded (19) $(66 \mathrm{mg}, 65 \%, 74 \%$ yield based on recovered 18a) as red brown oil: IR (neat) $v_{\max } 2922,2085,2049 \mathrm{~cm}^{-1} ;{ }^{1} \mathrm{H}$ NMR $\delta 5.90(\mathrm{~m}, 1 \mathrm{H})$, $5.16(\mathrm{~d}, \mathrm{~J}=17.1,1 \mathrm{H}), 5.10(\mathrm{~d}, \mathrm{~J}=10.7,1 \mathrm{H}), 4.6(\mathrm{~d}, \mathrm{~J}=11.7,4 \mathrm{H}), 3.5(\mathrm{~s}, 3 \mathrm{H}), 2.9(\mathrm{~m}, 2 \mathrm{H}), 2.42$ (m, 2H). ${ }^{13} \mathrm{C}$ NMR 199.8, 199.6, 136.8, 115.9, 98.6, 92.7, 92.6, 91.3, 72.6, 58.9, 41.2, 35.5, 32.7, MS (EI) m/e: $678(\mathrm{M}-2 \mathrm{CO})^{+}, 650(\mathrm{M}-3 \mathrm{CO})^{+}$; (ES-) $733(\mathrm{M}-\mathrm{H})^{-}, 705(\mathrm{M}-\mathrm{H}-\mathrm{CO})^{-}, 677(\mathrm{M}-\mathrm{H}-$ 2CO) ${ }^{-}, 649$ (M-H-3CO) ${ }^{-}$; HMMS (ES-) m/e for $\mathrm{C}_{23} \mathrm{H}_{14} \mathrm{Co}_{4} \mathrm{O}_{13}$ calcd (M+H-2CO) 676.7786, found 676.7767. A subsequent fraction contained the starting 18a (14.8 $\mathrm{mg}, 12 \%)$.

\section{Material on Deposit}

The ${ }^{1} \mathrm{H}$ NMR spectra of $\mathbf{4}$ and $\mathbf{5 a}$ and the ${ }^{13} \mathrm{C}$ NMR spectra of 3a-b, 5a-b, 6, 8a-d, 9a-b,

10a-b, 11, 12, 15, 16, 18a-b and 19 have been deposited as supplementary material. ${ }^{2}$

\section{Acknowledgements}

We are grateful for the research support of the Natural Sciences and Engineering Research Council of Canada (NSERC) and the University of Windsor. We wish to thank Lew Hryhorczuk

\footnotetext{
${ }^{2}$ Copies of materials on deposit may be purchased from the Depository of Unpublished Data, Document Delivery, CISTI, National Research Council of Canada, Ottawa, ON, K1A 0S2, Canada (http://www.nrc.ca/cisti/irm/unpub_e.shtml for information on ordering electronically)
} 
of the Wayne State University Mass Spectrometry Laboratory for the electrospray mass spectral work.

\section{References}

1. (a) J. R. Green. Curr. Org. Chem. 5, 809 (2001). (b) T. J. J. Müller. Eur. J. Org. Chem. 2021 (2001). (c) B. J. Teobald. Tetrahedron 58, 4133 (2002).

2. D. G. Hamilton and J. K. M. Sanders. Chem. Commun. 1749 (1998), and references therein.

3. For recent reviews on hexacarbonyldicobalt alkyne complexes, see: (a) M. E. Welker. Curr. Org. Chem. 5, 785 (2001). (b) M. J. Went. Adv. Organomet. Chem. 41, 69 (1997).

4. (a) T. Sugihara, M. Yamaguchi, and M. Nishizawa. Chem. Eur. J. 7, 1589 (2001). (b) K. M. Brummond and J. I. Kent. Tetrahedron 56, 3263 (2000). (c) Y. K. Chung. Coord. Chem. Rev. 188, 297 (1999). (c) A. J. Fletcher and S. D. R. Christie. J. Chem. Soc., Perkin Trans. 11657 (2000). (d) O. Geis and H.-G. Schmalz. Angew. Chem. Int. Ed. Engl. 37, 911 (1998).

5. (a) T. Sugihara, A. Wakabayashi, H. Takao, H. Imagawa, and M. Nishizawa. Chem. Commun. 2456 (2001). (b) S. U. Son, Y. K. Chung, and S.-G. Lee. J. Org. Chem. 65, 6142 (2000).

6. For example, see: a) N. M. Deschamps, J. H. Kaldis, P. E. Lock, J. F. Britten, and M. J. McGlinchey. J. Org. Chem. 66, 8585 (2001). b) E. J. Corey and C. J. Helal. Tetrahedron Lett. 36, 9153 (1995); c) J. Bach, R. Berenguer, J. Garcia, T. Loscertales, and J. Vilarrasa, J. Org. Chem. 61, 9021 (1996).

7. a) J. R. Green. Chem. Commun. 1751 (1998). b) M. M. Patel and J. R. Green. Chem. Commun. 509 (1999). c) R. Guo and J. R. Green. Chem. Commun. 2503 (1999). d) Y. Lu 
and J. R. Green. Synlett 243 (2001). e) R. Gibe and J. R. Green. Chem. Commun. 1550 (2002).

8. a) J. M. Palazón and A. S. Martín. Tetrahedron Lett. 36, 3549 (1995). b) M. Takase, T. Morikawa, H. Abe, and M. Inouye. Org. Lett. 5, 625 (2003). c) For selective ionization of an acetal function, see: T. F. Jamison, S. Samayati, W. E. Crowe, and S. L. Schreiber. J. Am. Chem. Soc. 119, 4353 (1997).

9. Non-selective disubstitution reactions of these complexes are known. For C-C forming reactions, see ref. 7c and a) G. G. Melikyan, M. A. Khan, and K. M. Nicholas. Organometallics 14, 2170 (1995). For C-X forming reactions, see: b) L. J. Hope-Weeks, M. J. Mays, and A. D. Woods. J. Chem. Soc., Dalton Trans. 1812 (2002). c) H. Amouri, C. Da Silva, B. Malézieux, R. Andrés, J. Vaissermann, and M. Gruselle. Inorg. Chem. 39, 5053 (2000). d) D. Díaz, T. Martín, and V. S. Martín. Org. Lett. 3, 3289 (2001).

10. a) J. S. Kim, Y. J. Lim, K. S. Im, C. J. Jung, C. O. Lee, J. Hong, and H. Lee. J. Nat. Prod. 62, 554 (1999), and references therein; b) Y. Seo, K. W. Cho, J.-R. Rho, J. Shin, and C. J. Sim. Tetrahedron 54, 447 (1998), and references therein; c) J. S. Kim, K. S. Im, J. H. Jung, Y.-L. Kim, J. Kim, C. J. Shim, and C.-O. Lee. Tetrahedron 54, 3151 (1998), and references therein.

11. a) G. Saha, M. K. Basu, S. Kim, Y.-J. Jung, Y. Adiyaman, M. Adiyaman, W. S. Powell, G. A. Fitzgerald, and J. Rokach. Tetrahedron Lett. 40, 7179 (1999), and references therein; b) Eicosanoids and Related Compounds in Plants and Animals, Edited by A. F. Rowley, H. Kühn, and T. Schewe. Princeton University, Princeton, 1998.

12. The Leukotrienes: Chemistry and Biology, Edited by L. W. Chakrin and D. M. Bailey. Academic, Orlando, 1984. 
13. R. Guo and J. R. Green. Synlett 746 (2000).

14. See, for example: T. Takahashi, T. Yokozawa, and T. Endo. Macromolecules 28, 866 (1995).

15. P. Rochet, J.-M. Vatèle, and J. Goré. Synthesis 795 (1994).

16. a) M. Berthelot, F. Besseau, and C. Laurence. Eur. J. Org. Chem. 925 (1998); b) F. Besseau, C. Laurence, and M. Berthelot. J. Chem. Soc., Perkin Trans. 2485 (1994).

17. a) P.-C. Maria and J.-F. Gal. J. Phys. Chem. 89, 1296 (1985); b) A. Rauk, I. R. Hunt, and B. A. Keay. J. Org. Chem. 59, 6808 (1994).

18. H. Mayr and H. Patz. Angew Chem. Int. Ed. Engl. 33, 938 (1994).

19. W. C. Still, M. Kahn and A. Mitra. J. Org. Chem. 43, 2923 (1978). 